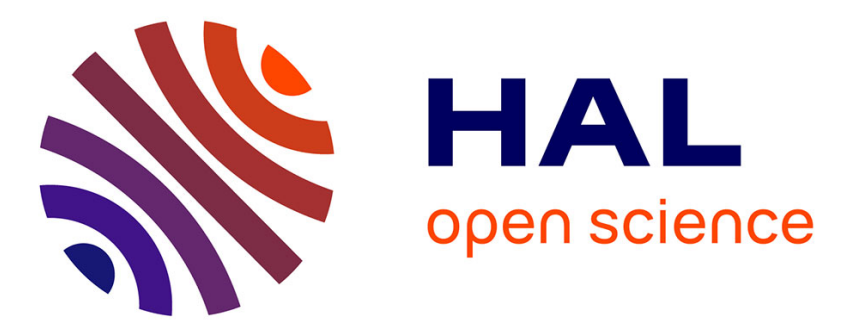

\title{
New Method of Simulation to Evaluate the Sensitivity to Oxidation of Lubricating Oils: An Aging Cell Coupled with Fourier Transform Infrared Spectroscopy
} F. Priéri, E. Gresser, Y. Le Dréau, J. Obiols, J. Kister

\section{- To cite this version:}

F. Priéri, E. Gresser, Y. Le Dréau, J. Obiols, J. Kister. New Method of Simulation to Evaluate the Sensitivity to Oxidation of Lubricating Oils: An Aging Cell Coupled with Fourier Transform Infrared Spectroscopy. Applied Spectroscopy, 2008, 62 (7), pp.810-816. 10.1366/000370208784909571 . hal03542805

\section{HAL Id: hal-03542805 \\ https://hal.science/hal-03542805}

Submitted on 25 Jan 2022

HAL is a multi-disciplinary open access archive for the deposit and dissemination of scientific research documents, whether they are published or not. The documents may come from teaching and research institutions in France or abroad, or from public or private research centers.
L'archive ouverte pluridisciplinaire HAL, est destinée au dépôt et à la diffusion de documents scientifiques de niveau recherche, publiés ou non, émanant des établissements d'enseignement et de recherche français ou étrangers, des laboratoires publics ou privés. 


\title{
New Method of Simulation to Evaluate the Sensitivity to Oxidation of Lubricating Oils: An Aging Cell Coupled with Fourier Transform Infrared Spectroscopy
}

\author{
F. PRIÉRI, E. GRESSER, Y. LE DRÉAU, J. OBIOLS, and J. KISTER* \\ Université Paul Cézanne, UMR CNRS 6171 Système Chimique Complexe, Laboratoire de Géochimie Organique Analytique et Environnement, \\ case 451, 13397 MARSEILLE cedex 20 (F.P., Y.L.D., J.K.); and Centre de recherche Total France (CReS), BP22 - 69360 Solaize Cedex (E.G., \\ J.O.)
}

\begin{abstract}
This study presents a new method for evaluating the oxidation of lubricating oils. An aging cell adapted to a Fourier transform infrared (FT-IR) spectrometer allows the continuous and direct study of the oxidative aging of base oils. During the test, oxidation bands appeared in the spectra (carbonyl bands around $1730 \mathrm{~cm}^{-1}$ ). The graphic representation of the carbonyl band modification-using a spectroscopic indexmakes it possible to monitor the evolution of the lubricant composition. Comparing the oxidation constants, determined from the kinetic plots of several base oils, makes it possible to evaluate their relative sensitivity. Index Headings: Oxidation stability; Lubricating oils; Fourier transform infrared spectroscopy; FT-IR spectroscopy; Aging cells; Simulation.
\end{abstract}

\section{INTRODUCTION}

A lubricant is a complex mixture of base oils and additives. The main purpose of lubricants is to lubricate the moving parts of a vehicle engine to reduce friction and wear and tear and increase the performance and the lifetime of the engine. The performance of a lubricant is increased by addition of additives such as pour-point depressants, antioxidants, dispersants, and detergents. New engine technologies lead to extreme heat stress, causing a deterioration of the properties of viscosity or the formation of deposits. The evolution of the lubricant's performance with time strongly depends on the resistance of the lubricant to oxidation. ${ }^{1-5}$

Therefore, a higher stability towards oxidation is required. It is important for formulators to determine the long-term stability of a lubricant. They should be able to predict the results of engine tests using fast, simple, and cheap laboratory tests. Different tests can be used such as the iron catalyzed oxidation test (ICOT), ${ }^{6}$ the rotating bomb oxidation test (RBOT) ${ }^{7}$ pressure differential scanning calorimetry (DSC), ${ }^{8}$ or the thinfilm oxygen uptake test (TFOUT). ${ }^{9}$ However, most of these tests are time consuming and do not give information about the chemical changes that may happen during these tests. Information is mainly obtained on the viscosity increases or the induction times or pressure differences.

Received 25 July 2008; accepted 1 April 2008.

* Author to whom correspondence should be sent. E-mail: jacky.kister@ univ-cezanne.fr.
Infrared spectrometry allows study of lubricant oxidation $^{10-14}$ and an ASTM method has been built using peak area increase calculation (ASTM D7214-07). ${ }^{15}$ However, these methods require sample preparation and the thermal oxidation system is separate from the spectrometer. Therefore, it is desirable to develop a new oxidative test that allows a rapid evaluation of the stability of lubricating base oils and lubricants toward oxidation and a better understanding of their structural evolution over time. Thus, it should make it possible not only to compare the base oils according to their stability but also to discriminate between them according to their structural evolution.

The aim of this study is to develop a fast, continuous, and direct monitoring of the slow evolution of lubricant oxidation, using Fourier transform infrared spectroscopy (FT-IR). This paper presents a new oxidation test that comes up to these expectations: an aging cell coupled with FT-IR spectroscopy. The cell allows lubricating base oils to be oxidized under controlled atmosphere and temperature. FT-IR allows the qualitative and semi-quantitative analysis of the chemical composition of base oils. This method makes it possible to discover the functional and structural groups that account for the chemicals formed by aging, without destroying the oil's internal balance.

\section{EXPERIMENTAL}

Samples. The lubricating base oils used for this study were obtained from TOTAL Research Center, Solaize, France. They were selected from the different API groups in order to cover a wide range of applications.

"NS E" represents Group I basestocks, characterized by high sulfur and aromatic contents. "HT C" represents Group II basestocks. "HI J" and "HI+S1" represent Group III basestocks. "PAO" corresponds to the synthetic poly-alpha-olefin base oils of Group IV.

Infrared Spectroscopy. Fourier transform infrared spectra were measured on a Nicolet Protégé 460 spectrometer coupled with a Nicolet Nic-Plan infrared microscope fitted with a mercury cadmium telluride (MCT) detector cooled with liquid nitrogen. The standard analytical conditions were $15 \times$ infrared 


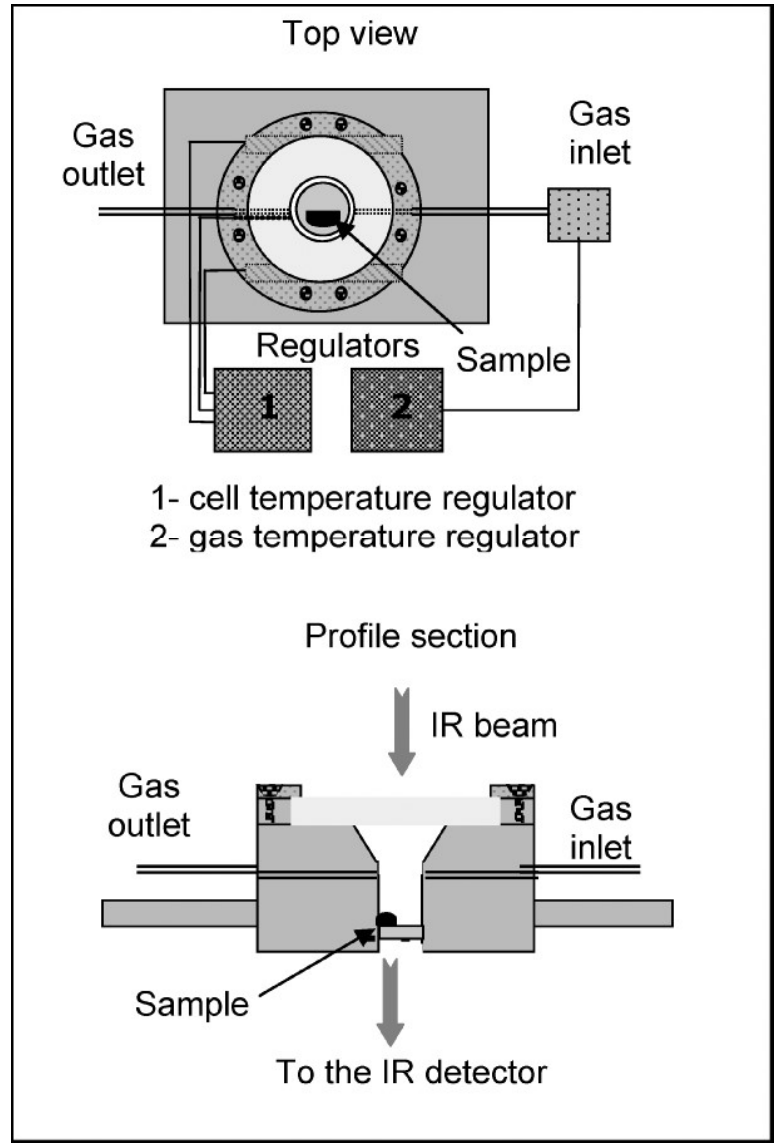

FIG. 1. Schematic showing the principle of the aging cell.

objective, beam size of $100 \times 100 \mu \mathrm{m}$. The spectra were acquired using Omnic 4.1. Nicolet software. Sixty-four (64) scans of symmetrical interferograms were averaged and the spectrum was calculated from 4000 to $650 \mathrm{~cm}^{-1}$ at $4 \mathrm{~cm}^{-1}$ spectral resolution.

The Aging Cell: Design and Development. The aging test was run in an aging cell developed in our laboratory to study the structural evolution of fluid fossil organic material ${ }^{16}$ during aging. This aging test corresponds to a thin layer test. The cell was fitted in the motorized stage of the microscope so that it under-regulated thermo-oxidizing conditions.

The aging cell consisted of a metallic body heated by two heating cartridges (Fig. 1). These two cartridges were connected to a regulator (WATLOW 988), itself connected to

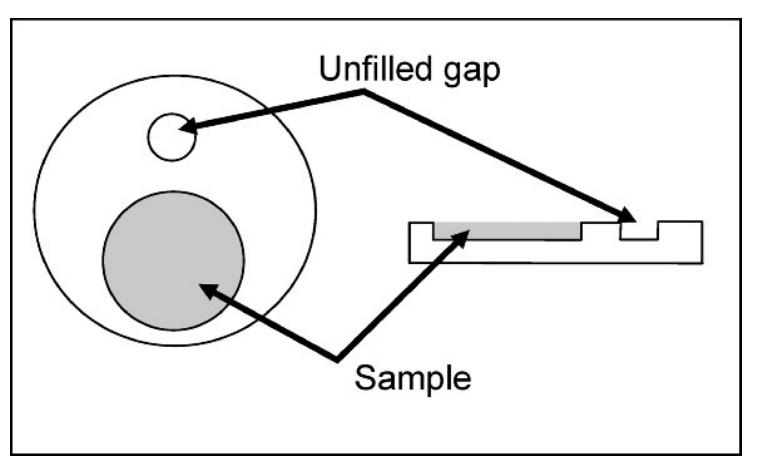

FIG. 2. $\mathrm{NaCl}$ window allowing the study of fluid materials.

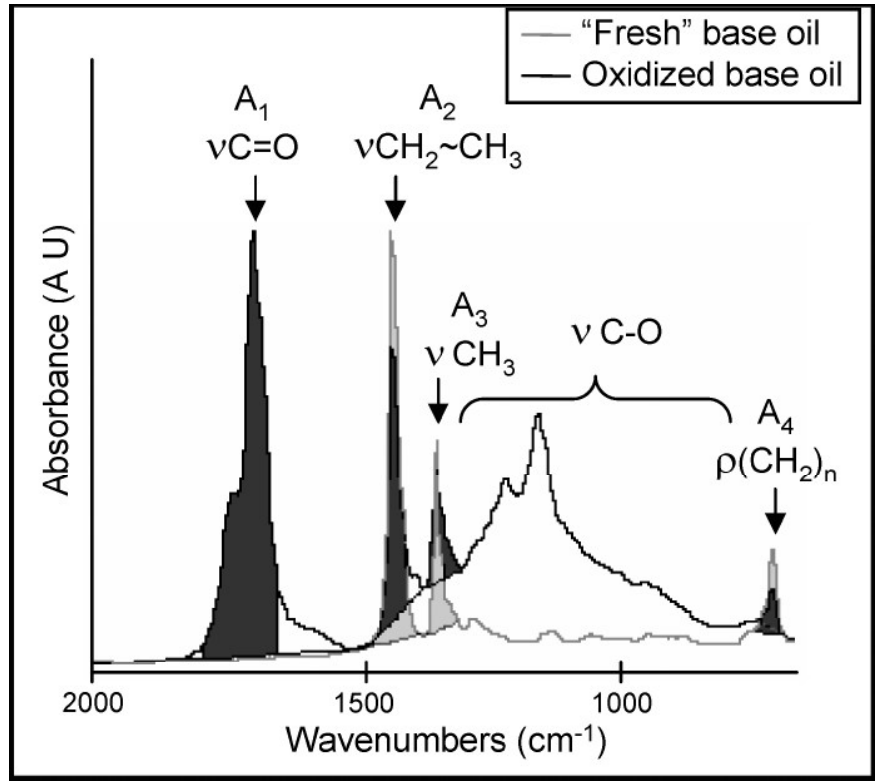

FIG. 3. FT-IR spectra of HI+S1 base oil before and after oxidation between 2000 and $650 \mathrm{~cm}^{-1}$.

a temperature probe fitted in the center of the cell. A heated gas flow was flushed through the cell. The gas heating block was connected to a second regulator (WATLOW 988). The system was equipped with a by-pass to select the gas. Analyses could be performed either under oxidant gas (Synthetic air $\left(80 \% \mathrm{~N}_{2}\right.$, $20 \% \mathrm{O}_{2}$ ) Air liquide, 99\% purity) or under neutral gas (argon, Air liquide, $99 \%$ purity), allowing the thermal effect to be distinguished from the oxidative effect during simulated aging. The cell is always maintained at atmospheric pressure thanks to the gas outlet.

The sample was supported by a $\mathrm{NaCl}$ window $(13 \times 2 \mathrm{~mm})$. Two $1 \mathrm{~mm}$ deep cavities were created in this $\mathrm{NaCl}$ window. The bigger cavity (diameter, $5 \mathrm{~mm}$ ) was to contain the sample, the smaller one (diameter, $0.5 \mathrm{~mm}$ ) did not contain any sample (Fig. 2). Thus, it was possible to collect a background spectrum at any time.

The window was fitted at the bottom of the cell. A removable upper $\mathrm{NaCl}$ window $(30 \mathrm{~mm} \times 2 \mathrm{~mm})$ was fixed by some screws during analysis. The cell was fixed on a Teflon stand, itself fitted in the motorized stage of the microscope. Using a Teflon stand reduces the diffusion of heat to the motorized stage so that its movement is not affected.

Continuous Collection of Spectra Within the Heating Cell. Six milligrams $(6 \mathrm{mg})$ of oil were placed in the $5 \mathrm{~mm}$ diameter cavity of the $\mathrm{NaCl}$ window and heated from $25^{\circ} \mathrm{C}$ up to a chosen temperature under argon at $11{ }^{\circ} \mathrm{C} \mathrm{min}-1$ for around $15 \mathrm{~min}$. Then, the heating was maintained at the chosen temperature under synthetic air during the rest of the experiment. Spectra were collected every $15 \mathrm{~min}$ during the oxidation process.

The more the temperature increases the more the oil becomes fluid and the more it spreads. The gas flow should be sufficient to ensure either an oxidizing atmosphere or a neutral atmosphere but should not sweep away the oil. Thus, the non-oxidizing conditions in the first fifteen minutes are reached thanks to an argon gas flow of $80 \mathrm{~mL} \mathrm{~min}{ }^{-1}$. The optimum air flow was found to be equal to $50 \mathrm{~mL} \mathrm{~min}^{-1}$.

Figure 3 shows typical FT-IR spectra before and after 


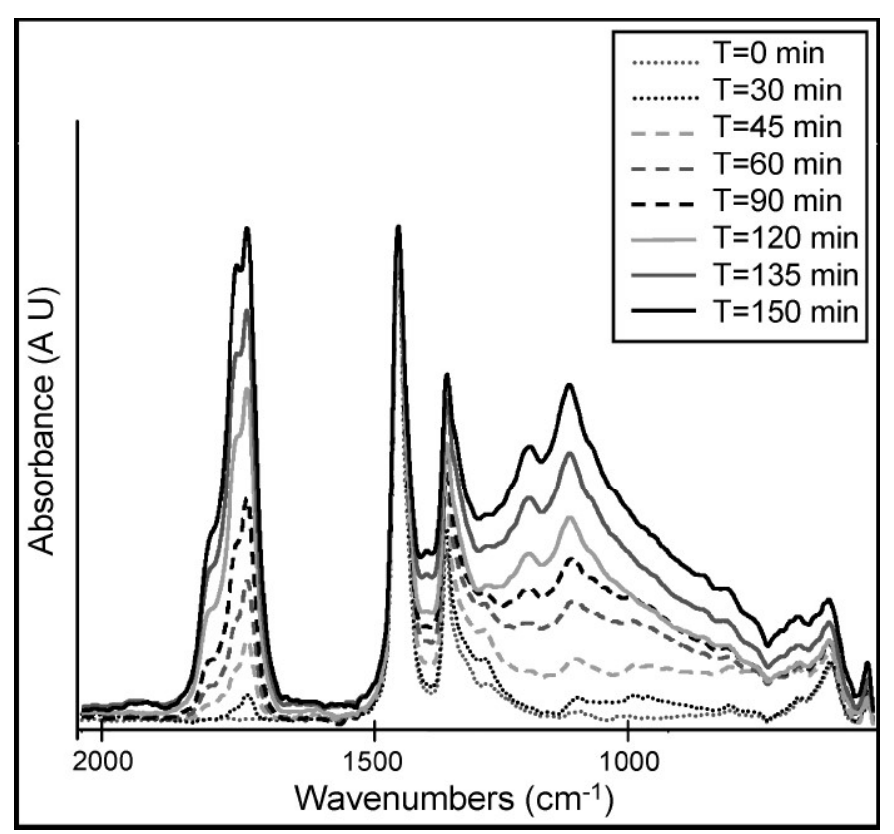

FIg. 4. Spectra of $\mathrm{HI}+\mathrm{S} 1$ at different times of oxidation at $170{ }^{\circ} \mathrm{C}$ between 2000 and $650 \mathrm{~cm}^{-1}$.

oxidation of the HI+S1 base oil between 2000 and $650 \mathrm{~cm}^{-1}$. In addition to bands at 1460 and $1375 \mathrm{~cm}^{-1}$, attributed to the bending vibration of the $\mathrm{CH}_{2}$ and $\mathrm{CH}_{3}$ groups existing in "fresh oil", the FT-IR spectra obtained during the aging show absorption bands relative to carbonyl species corresponding to the oxidation products. These bands correspond to the $v_{\mathrm{C}=\mathrm{O}}$ stretching mode from 1850 to $1685 \mathrm{~cm}^{-1}$ (acids, ketones, esters, anhydrides, and lactones) and to the $v_{\mathrm{C}-\mathrm{O}}$ stretching mode from 1300 to $850 \mathrm{~cm}^{-1}$. Assignments were made according to the works of Coates and Setti. ${ }^{17}$

The oil aging was followed by calculating a spectroscopic index named the carbonyl index. This index was calculated from the band areas measured from valley to valley. ${ }^{18-21}$ The band areas were considered rather than the band heights in order to obtain a finer index. The following areas were defined (Fig. 3):

$A_{1}$ : from 1850 to $1685 \mathrm{~cm}^{-1}$ (multiple $\mathrm{C}=\mathrm{O}$ bands)

$A_{2}$ : from 1502 to $1419 \mathrm{~cm}^{-1}$ (bands at 1467 and $1450 \mathrm{~cm}^{-1}$ ) $A_{3}$ : from 1396 to $1369 \mathrm{~cm}^{-1}$ (band at $1378 \mathrm{~cm}^{-1}$ )

The carbonyl index is given by the following equation:

$$
I_{\mathrm{C}=\mathrm{O}}=A_{1} /\left(A_{1}+A_{2}+A_{3}\right)
$$

Bulk Oxidation Tests. Two bulk oxidation tests were used. The first one was adapted from the iron catalyzed oxidation test (ICOT) for this study (modified ICOT). The protocol of the ICOT, used in the oil industry, is described by Faure et al. ${ }^{22}$ and Obiols. ${ }^{23}$ Twenty-seven grams (27 g) of base oil were oxidized in test tubes placed in a thermo-regulated bath (170 ${ }^{\circ} \mathrm{C}$ ) for $72 \mathrm{~h}$. Each test tube was equipped with an air gas inlet and an oxidized gas outlet. The air flow was $10 \mathrm{~L} \mathrm{~h}^{-1}$. This modified ICOT was performed without catalyst. A sample of $20 \mu \mathrm{L}$ was taken every hour and analyzed by FT-IR microscopy, as previously described. The fresh base oil and the final oxidized base oil after $72 \mathrm{~h}$ of oxidation were

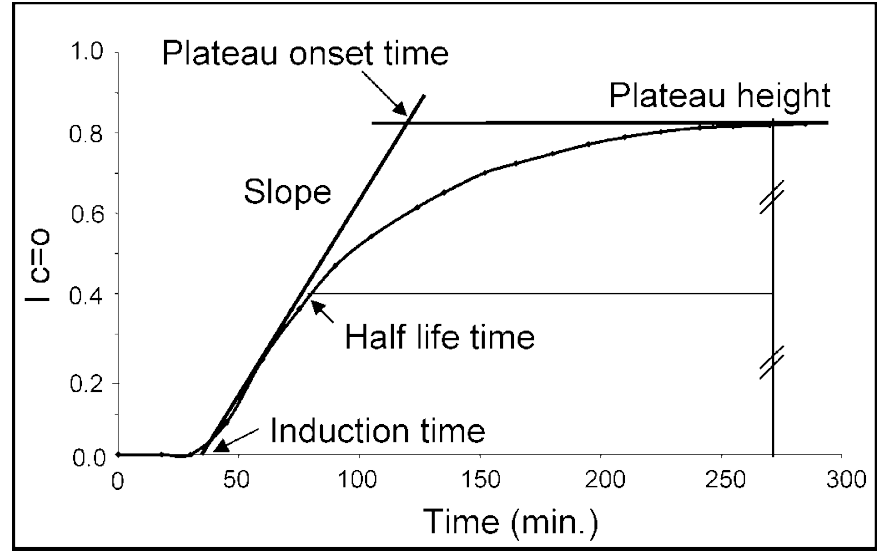

FIG. 5. Evolution of the carbonyl index $(\mathrm{Ic}=0)$ versus time for $\mathrm{HI}+\mathrm{S} 1$ heated to $170{ }^{\circ} \mathrm{C}$ in the aging cell.

recovered and placed in an automatic viscosimeter. The ratio between the initial viscosity $\left(V_{\mathrm{i}}\right)$ and the final viscosity $\left(V_{\mathrm{f}}\right)$ gives the kinematic viscosity increase $(K V I)$ :

$$
K V I=\left[\left(V_{\mathrm{f}}-V_{\mathrm{i}}\right) / V_{\mathrm{i}}\right] \times 100
$$

The second test (laboratory oxidation test, LOT), carried out on $250 \mathrm{~g}$ of oil, used a laboratory apparatus consisting of a 500 $\mathrm{mL}$ three-necked flask, a right condenser, a thermo-controlled heating bath $\left(160{ }^{\circ} \mathrm{C}\right)$, a controlled flow of synthetic air for bubbling (50 mL min ${ }^{-1}$ ) and a septum to take a $1 \mathrm{~mL}$ sample every hour. Oil is agitated by a magnetic stirrer. Each sample was analyzed by FT-IR microscopy.

The flows used in each test allow optimal oxygen diffusion (at least at the beginning of each test).

\section{RESULTS AND DISCUSSION}

Choice of Experimental Conditions. The use of the carbonyl index eliminates the constraints due to the sample thickness and thus to the spectrum intensity. Then, it is possible to compare the different tests on the same scale. Figure 4 shows a set of spectra collected during the oxidation of $\mathrm{HI}+\mathrm{S} 1$ in the heating cell at $170{ }^{\circ} \mathrm{C}$. The carbonyl index was calculated after the integration of all the spectra and its evolution was graphically represented as a function of the oxidation time (i.e., a kinetic plot) (Fig. 5).

The kinetic plot starts with an induction period, and then the oxidation itself starts. The exponential evolution is representative of the oxidation up to a maximum called the plateau. Then the oxidation stops. The kinetic plot could be interpreted according to five constants: (1) Induction time (It): time corresponding to the beginning of the oxidation process; (2) Slope: representative of the rate of the oxidation reaction; (3) Half life time (Hlt): time necessary to reach $50 \%$ of the plateau height; (4) Plateau onset time (Pot): time corresponding to the end of the oxidation; and (5) Plateau height $(\mathrm{Ph})$ : maximum oxidation rate.

Common tests usually oxidize oils at high temperatures ${ }^{6-9,24}$ (160-180 $\left.{ }^{\circ} \mathrm{C}\right)$. This aging cell should be able to oxidize oil rapidly whatever the oil. Five temperatures were thus tested with $\mathrm{HI}+\mathrm{S} 1: 140,150,160,170$, and $180{ }^{\circ} \mathrm{C}$, as shown in Fig. 6. The oxidation constants obtained from these five kinetic plots are given in Table I. The temperatures of 140 and $150{ }^{\circ} \mathrm{C}$ were dismissed because the induction times $(238.6 \mathrm{~min}$ and 


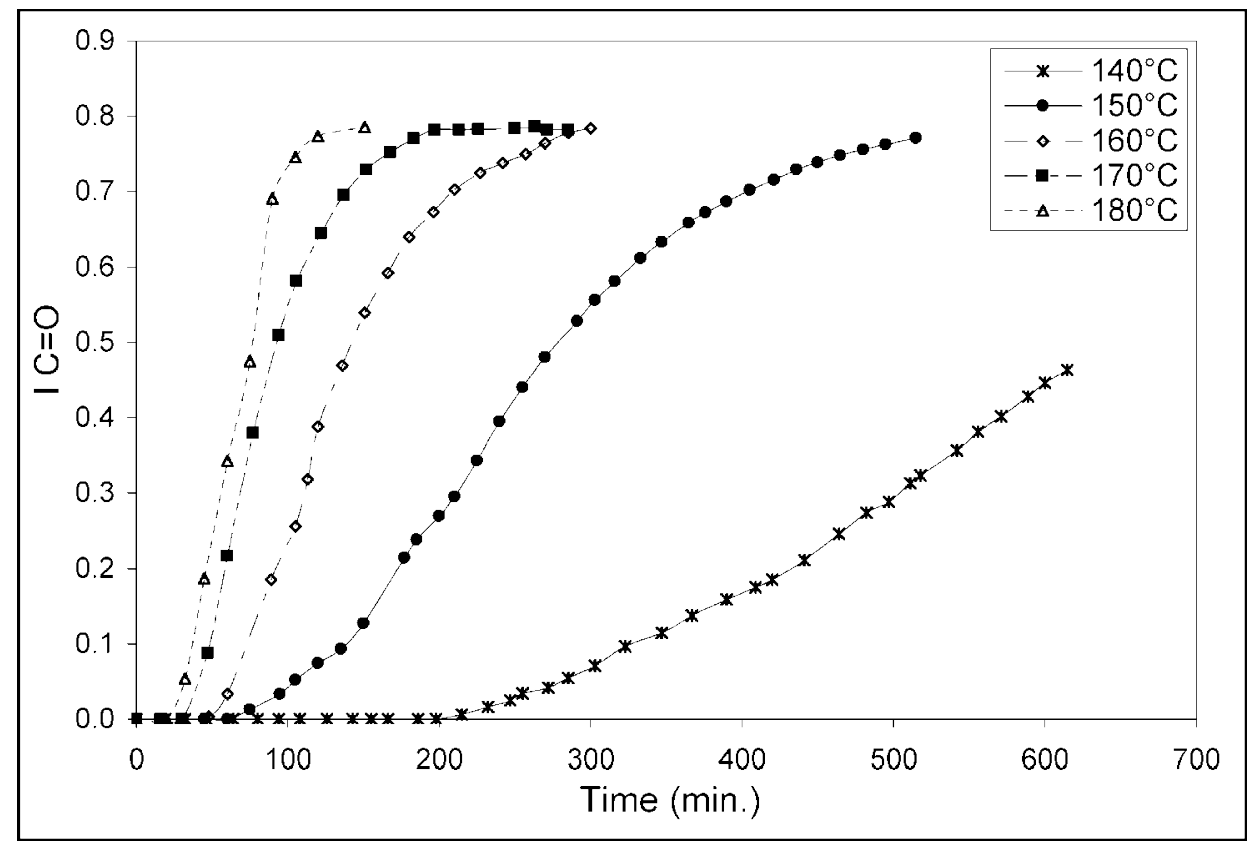

FIG. 6. Kinetic plots of $\mathrm{HI}+\mathrm{S} 1$ at $140,150,160,170$, and $180{ }^{\circ} \mathrm{C}$.

TABLE I. Oxidation constants of $\mathrm{HI}+\mathrm{S} 1$ heated to $140,150,160,170$, and $180{ }^{\circ} \mathrm{C}$.

\begin{tabular}{crccccr}
\hline $\begin{array}{c}\text { Temperature } \\
\left({ }^{\circ} \mathrm{C}\right)\end{array}$ & It & Slope & Hlt & Pot & Ph & Ft \\
\hline 140 & 238.6 & 0.0014 & No & No & No & 615 \\
150 & 86.5 & 0.0028 & 242.0 & 357.2 & 0.79 & 515 \\
160 & 55.3 & 0.0055 & 132.5 & 194.8 & 0.81 & 330 \\
170 & 32.0 & 0.0079 & 81.2 & 131.8 & 0.80 & 240 \\
180 & 19.8 & 0.0097 & 67.6 & 103.6 & 0.82 & 165
\end{tabular}

${ }^{\mathrm{a}} \mathrm{It}=$ induction time; $\mathrm{Hlt}=$ half-life time $\mathrm{Pot}=$ plateau onset time; $\mathrm{Ph}=$ plateau height; $\mathrm{Ft}=$ final time. No $=$ not observed. Each time is expressed in min.

TABLE II. Oxidation constants of $\mathrm{HI}+\mathrm{S} 1$ and $\mathrm{HI} \mathrm{J}$ heated to 160 and 170 ${ }^{\circ} \mathrm{C}$.

\begin{tabular}{llcccccc}
\hline & & It & Slope & Hlt & Pot & Ph & Ft \\
\hline $160{ }^{\circ} \mathrm{C}$ & HI + S1 & 55.3 & 0.0055 & 194.8 & 132.5 & 0.81 & 330 \\
& HI J & 72.0 & 0.0051 & 203.6 & 130.1 & 0.79 & $\mathrm{No}^{\mathrm{a}}$ \\
$170{ }^{\circ} \mathrm{C}$ & HI $+\mathrm{S} 1$ & 32.0 & 0.0079 & 81.2 & 131.8 & 0.80 & 240 \\
& HI J & 42.9 & 0.0074 & 84.1 & 127.4 & 0.79 & $\mathrm{No}^{\mathrm{a}}$
\end{tabular}

${ }^{\mathrm{a}} \mathrm{No}=$ not observed. Each time is expressed in min.

TABLE III. Repeatability of the test on $\mathrm{HI}+\mathrm{S} 1$ heated to $170{ }^{\circ} \mathrm{C}$.

\begin{tabular}{lrrrrr}
\hline & $\begin{array}{c}\text { It } \\
(\mathrm{min})\end{array}$ & Slope & $\begin{array}{c}\text { Hlt } \\
(\mathrm{min})\end{array}$ & $\begin{array}{c}\text { Pot } \\
(\mathrm{min})\end{array}$ & $\mathrm{Ph}$ \\
\hline Test 1 & 32.8 & 0.0074 & 85.3 & 127.2 & 0.83 \\
Test 2 & 31.3 & 0.0079 & 81.3 & 131.8 & 0.79 \\
Test 3 & 30.0 & 0.0073 & 80.6 & 129.6 & 0.85 \\
Test 4 & 31.5 & 0.0074 & 89.5 & 137.1 & 0.83 \\
Test 5 & 32.6 & 0.0079 & 81.1 & 131.8 & 0.80 \\
Test 6 & 33.5 & 0.0075 & 82.6 & 123.2 & 0.83 \\
Mean & 32.0 & 0.0076 & 83.4 & 130.1 & 0.82 \\
Standard deviation & 1.2 & 0.0002 & 3.1 & 4.3 & 0.02 \\
Coefficient of variance (\%) & 3.6 & 3.2 & 3.8 & 3.3 & 2.5 \\
\hline
\end{tabular}

$86.5 \mathrm{~min}$, respectively) were too long. On the contrary, at 180 ${ }^{\circ} \mathrm{C}$ the induction time was too short $(19.8 \mathrm{~min})$ and the slope was too steep. This can lead to errors in the classification of base oils according to their sensitivity to oxidation. Therefore, this temperature was also dismissed. In order to choose between 160 and $170{ }^{\circ} \mathrm{C}$, the results obtained for $\mathrm{HI}+\mathrm{S} 1$ were compared with those obtained for HI J. They are given in Table II. HI $+\mathrm{S} 1$ was the most sensitive to oxidation. The difference between the induction times of the two oils was $\approx 17$ min at $160{ }^{\circ} \mathrm{C}$ and $\approx 10 \mathrm{~min}$ at $170{ }^{\circ} \mathrm{C}$. The difference between their slopes was nearly the same for both temperatures. Therefore, the discrimination between the two oils was better at $160{ }^{\circ} \mathrm{C}$ but took more time. Finally, $170{ }^{\circ} \mathrm{C}$ is the most suitable temperature. It makes it possible to observe complete kinetics (up to the plateau height) and to obtain the five required oxidation constants.

To evaluate the repeatability of the method, the test was carried out six times by the same experimenter on $\mathrm{HI}+\mathrm{S} 1$ at $170{ }^{\circ} \mathrm{C}$. Table III summarizes the oxidation constants of each kinetic plot, their means, and their standard deviations. The coefficient of variance (CV), defined by the following equation (Eq. 3), is a repeatability evaluation tool:

$$
\mathrm{CV} \%=(\text { Standard deviation } / \text { Mean }) \times 100
$$

None of the CVs given in Table III exceeded 3.8\%; therefore, the test can be considered repeatable and was in accordance with other tests. ${ }^{8}$

Comparison with the Modified Iron Catalyzed Oxidation Test. The samples NS E, HT C, HI J, and PAO were oxidized using both the modified ICOT (a bulk oxidation test) and the heating aging cell (a thin layer test). Graphical and numerical results are shown in Fig. 7 and Table IV. Base oil can be considered resistant to oxidation if its induction time, its halflife time, and its plateau onset time are high and if its slope is weak and its plateau height is low. The HT C base oil has the lowest times - in particular the lowest induction time $(=38.6$ min) _ and the highest plateau height. The induction times and 


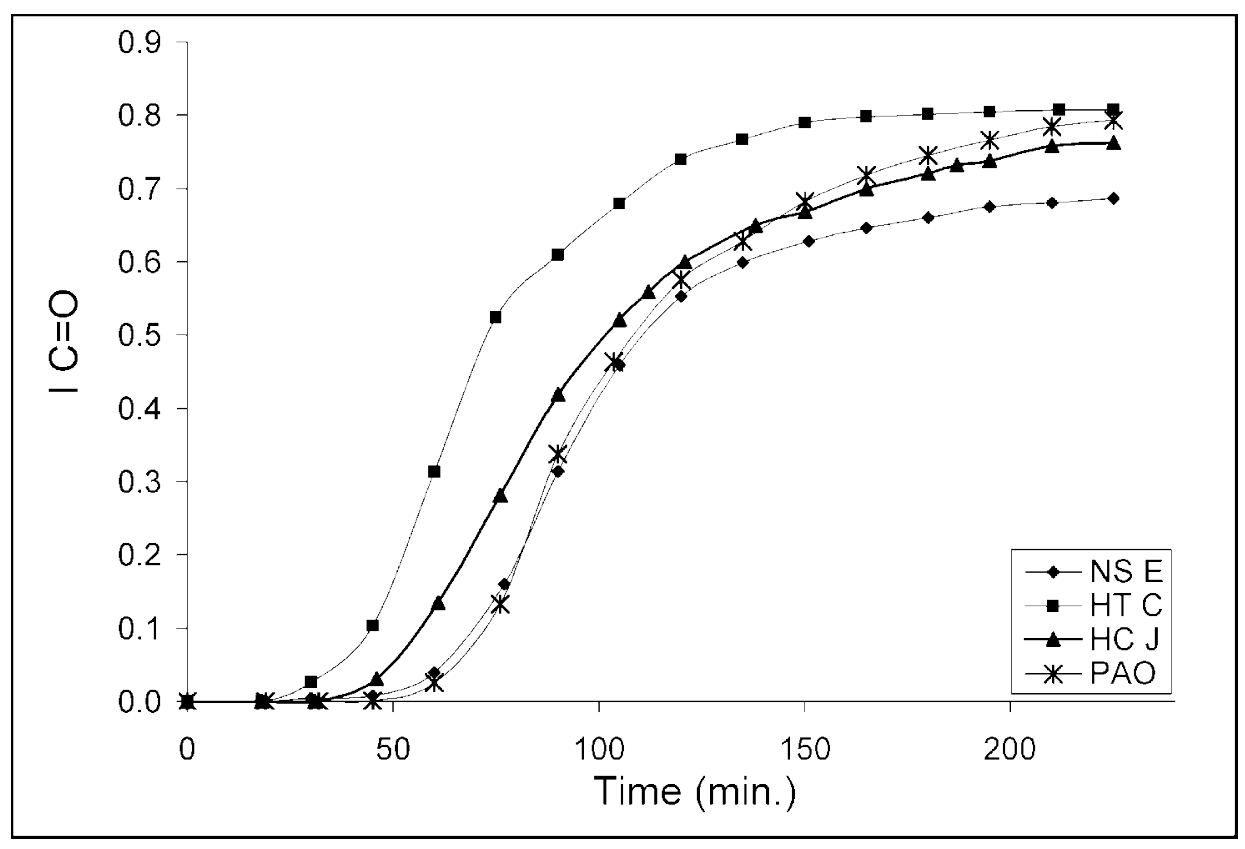

FIG. 7. Kinetic plots of NS E, HT C, HC J, and PAO at $170{ }^{\circ} \mathrm{C}$.

the slopes of PAO and NS E are similar, but the plateau height of NS E is lower than that of PAO. HI J is intermediate between HT C and PAO/NS E. Therefore, according to each constant, orders of sensitivity to oxidation are proposed in Table V. The base oils are classified from the most sensitive to the least sensitive and a global order of sensitivity is proposed as follows:

$$
\mathrm{HT} \mathrm{C}>\mathrm{HI} \mathrm{J}>\mathrm{PAO}>\mathrm{NS} \mathrm{E}
$$

This order is in accordance with the characteristics of the base oils. Actually, group II base oils are more sensitive to oxidation than group III base oils, themselves more sensitive than group IV base oils. ${ }^{25}$ The result obtained for group I base oils is due to their content of sulfur and aromatic compounds, which are natural antioxidants. ${ }^{26}$

Table IV shows ICOT results for these base oils. ICOT gives an idea of the oxidation sensitivity through the kinematic viscosity increase. The base oils are classified from the most sensitive to the least sensitive as follows:

$$
\mathrm{HT} \mathrm{C}>\mathrm{PAO}>\mathrm{HI} \mathrm{J}>\mathrm{NS} \mathrm{E}
$$

In comparison with the previous order, PAO and $\mathrm{HI} \mathrm{J}$ are inverted, but the order found with ICOT is similar to the one found by using the plateau height (Table V). This can be

TABLE IV. Oxidation constants of all the base oils. ${ }^{\text {a }}$

\begin{tabular}{lcccccr}
\hline & It (min) & Slope & Hlt (min) & Pot (min) & Ph & KVI (\%) \\
\hline NS E & 58.4 & 0.0079 & 96.2 & 134.4 & 0.69 & 16.0 \\
HT C & 34.7 & 0.0101 & 74.1 & 104.1 & 0.82 & 3206.9 \\
HC J & 42.9 & 0.0074 & 84.1 & 127.4 & 0.79 & 2002.7 \\
PAO & 58.2 & 0.0086 & 103.1 & 147.0 & 0.79 & 2700.1 \\
\hline
\end{tabular}

${ }^{a} \mathrm{KVI}(\%)=$ kinematic viscosity increase in percent obtained after the modified ICOT. explained by the fact that ICOT is a technique that makes it possible to measure the final residue after $72 \mathrm{~h}$ of oxidation.

Index Validity. The modified ICOT was performed on $\mathrm{HI}+\mathrm{S} 1$ at $160^{\circ} \mathrm{C}$ to confirm the oxidation constants obtained by the thin layer test carried out with the aging cell $(\mathrm{HI}+\mathrm{S} 1,160$ $\left.{ }^{\circ} \mathrm{C}\right)$. The carbonyl index was calculated from the spectrum of each sample taken every hour. The kinetic plots are shown in Fig. 8. The oxidation constants are as follows: $\mathrm{It}=52.8 \mathrm{~min}$, Slope $=0.0361$, Hlt $=600 \mathrm{~min}(10 \mathrm{~h}), \mathrm{Pot}=18 \mathrm{~h}$, and $\mathrm{Ph}=$ 0.612. The comparison of the kinetic plots obtained with the modified ICOT and with the aging cell shows that the induction times are very similar whatever the oxidized volume: $55.3 \mathrm{~min}$ for the oxidation by the aging cell and $52.8 \mathrm{~min}$ for the oxidation by the modified ICOT.

To confirm this result, a bulk oxidation test by LOT was carried out on $250 \mathrm{~g}$ of $\mathrm{HI}+\mathrm{S} 1$ at $140{ }^{\circ} \mathrm{C}$. The kinetic plot is compared to the one obtained with the aging cell (HI+S1, $140{ }^{\circ} \mathrm{C}$ ) (Fig. 9). The induction times are similar: $232.9 \mathrm{~min}$ with the cell and $230.3 \mathrm{~min}$ with the LOT. The slopes obtained are very different. This means that the ratio of oxygenated compounds formed is not proportional to the quantity of oil. The propagation of the peroxyl radicals ${ }^{27,28}$ may be more difficult if the quantity of oil is significant.

The induction time is an oxidation constant non-sensitive to the quantity of oil. Therefore, this constant can be used as an internal reference because it can be transposable from a bulk

TABLE V. Classification of the base oils according to their sensitivity to oxidation based on their oxidation parameters.

\begin{tabular}{lcccc}
\hline & $\begin{array}{c}\text { Most } \\
\text { sensitive }\end{array}$ & $>$ & $>$ & $\begin{array}{c}\text { Least } \\
\text { sensitive }\end{array}$ \\
\hline Induction time & HT C & HC J & PAO & NSE \\
Slope & HTC & HC J & NSE & PAO \\
Half-life time & HT C & HC J & NSE & PAO \\
Plateau onset time & HT C & HC J & NSE & PAO \\
Plateau height & HT C & PAO & HC J & NSE \\
\hline
\end{tabular}




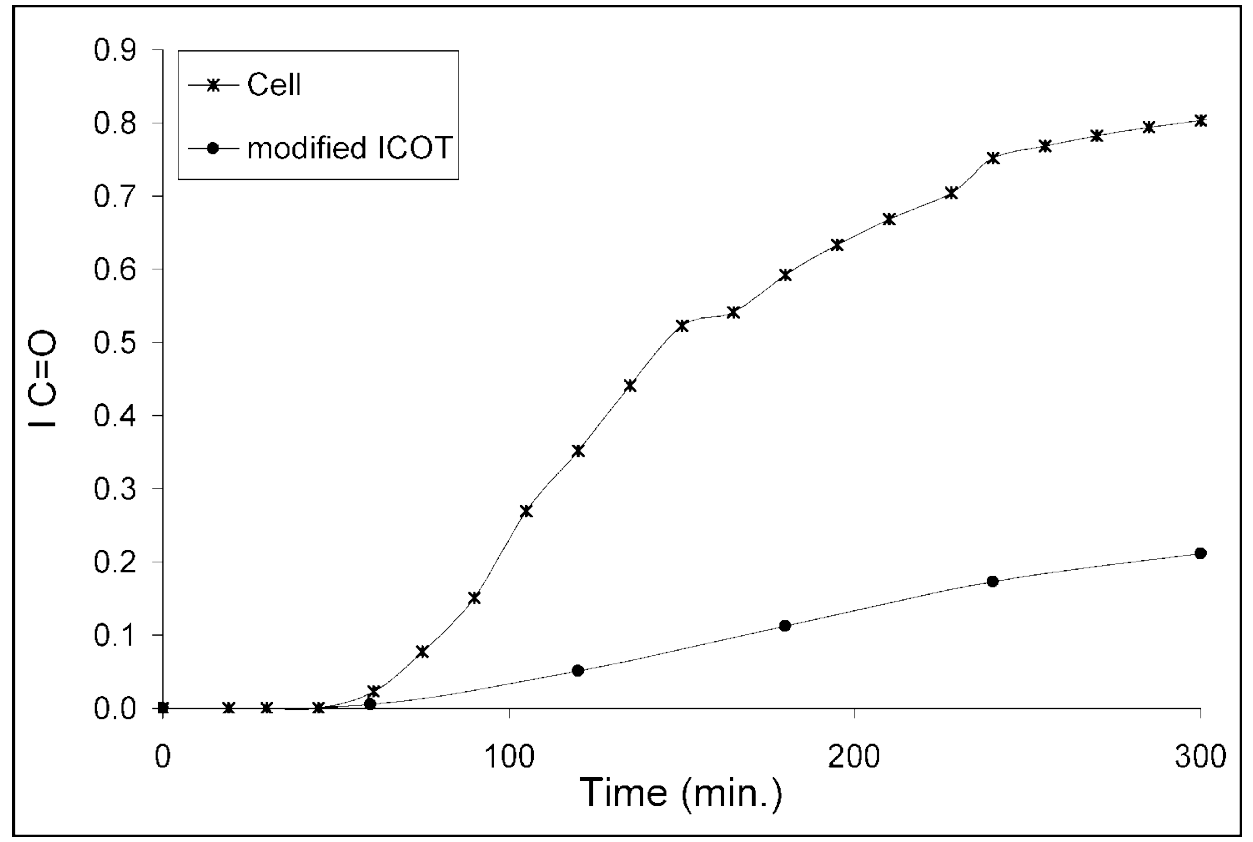

FIG. 8. Kinetic plots of $\mathrm{HI}+\mathrm{S} 1$ at $160^{\circ} \mathrm{C}$ obtained by the aging cell and with the modified ICOT.

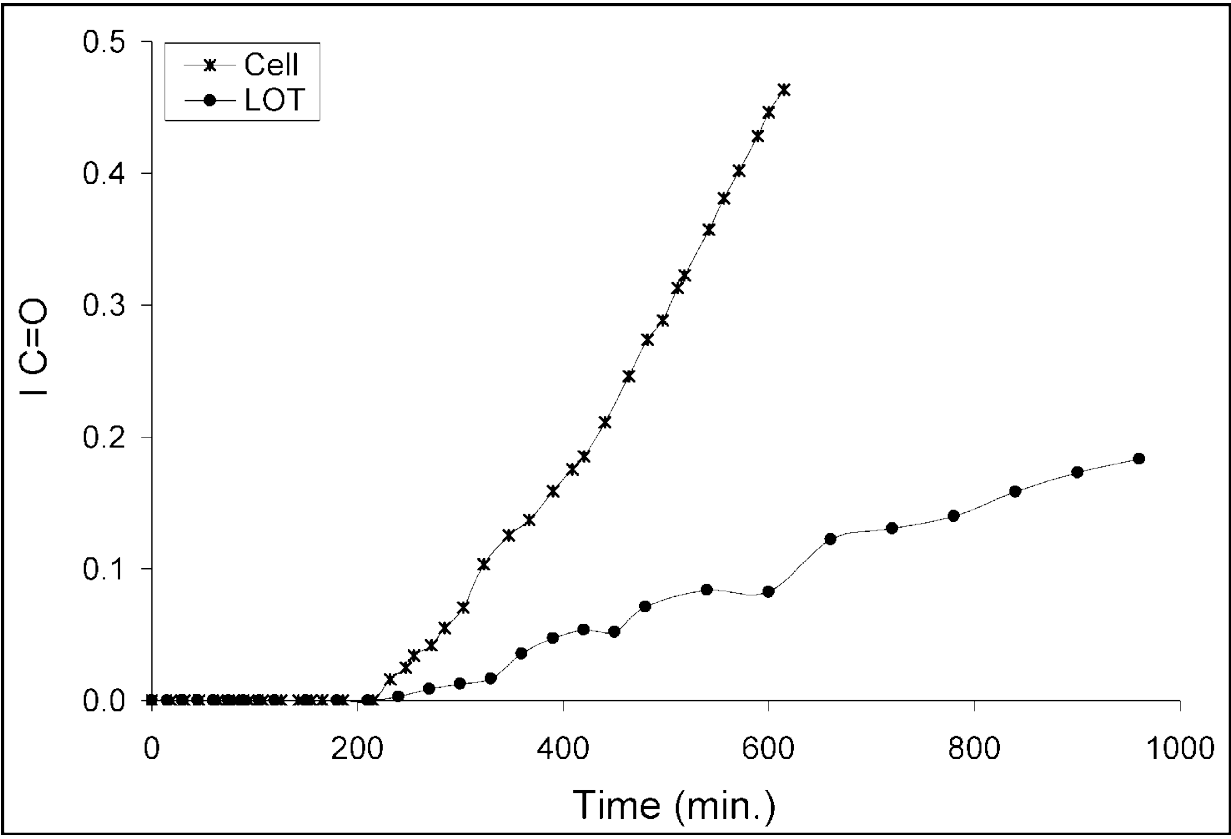

FIG. 9. Kinetic plots of $\mathrm{HI}+\mathrm{S} 1$ at $140{ }^{\circ} \mathrm{C}$ obtained by the aging cell and with the LOT.

oxidation test to the thin layer test using the aging cell whatever the temperature.

\section{CONCLUSION}

The aging cell allows the discrimination between base oils. Moreover, an FT-IR analysis of the oxidation products in each phase (induction, exponential, and terminal phase) is possible. This study has demonstrated that the induction time is an intrinsic characteristic of oil. Moreover, the classification obtained according to the plateau height (results obtained using the aging cell) is the same as the one obtained according to the viscosity increase (modified ICOT results). Therefore, the information obtained using the aging cell is in accordance with the information obtained using other techniques, and they are even obtained more rapidly and from smaller sample quantities. Therefore, this new method should be an interesting alternative to the usual oxidation tests.

1. B. Bourdoncle and G. Parc, Revue de l'Institut Français du Pétrole XXIV, 940 (1969).

2. M. T. Devlin, M. A. Grina, and T. C. Jao, Symposium on recent advances in the chemistry of lubricant additives, 218th national meeting, ACS (New Orleans, LA, August 22-26, 1999), p. 314. 
3. S. Gunsel, E. E. Klaus, and J. L. Duda, Lub. Eng. 44, 703 (1987).

4. R. K. Jensen and S. Korcek, Symposium on recent advances in the chemistry of lubricant additives, 218th national meeting, ACS (New Orleans, LA, August 22-26, 1999), p. 322.

5. R. K. Jensen, S. Korcek, and M. D. Johnson, Lub. Sci. 114, 14 (2001).

6. D. Faure, J. C. Hipeaux, Y. Guevellou, and A. Legros, Tribo. J. 5, 337 (1999).

7. T. M. Warne and P. C. Vienna, Lub. Eng. 40, 211 (1982).

8. B. K. Sharma and A. J. Stipanovic, Thermochim. Acta 402, 1 (2003).

9. C. S. Ku and S. M. Hsu, Lub. Eng. 40, 75 (1984).

10. F. R. Van de Voort, J. Sedman, R. Cocciardi, and S. Juneau, Talanta 72, 289 (2007)

11. F. R. Van de Voort, J. Sedman, R. Cocciardi, and D. Pinchuk, Tribol. Trans. 49, 410 (2006).

12. A. Borin and R. J. Poppi, Vib. Spectrosc. 37, 27 (2005).

13. D. Du, S. S. Kim, W. S. Moon, S. B. Jin, and W. S. Kwon, Thermochim. Acta 407, 17 (2003).

14. J. Dong, F. R. van de Voort, A. A. Ismail, E. Akochi-Koblé, and D. Pinchuk, Lubr. Eng. 6, 12 (2000).

15. ASTM D7214-07. Standard test method for determination of the oxidation of used lubricants by FT-IR using peak area increase calculation (ASTM International Standards, Gaithersburg, MD).
16. J. Lamontagne, F. Durrieu, J.-P. Planche, V. Mouillet, and J. Kister, Anal. Chim. Acta 444, 241 (2001).

17. J. P. Coates and L. C. Setti, ASLE Trans. 29, 394 (1986).

18. H. Masmoudi, Y. Le Dréau, P. Piccerelle, and J. Kister, Int. J. Pharm. 289, 117 (2005).

19. V. Mouillet, J. Kister, C. Saury, D. Martin, and J. P. Planche, Proceedings of Eurasphalt and Eurobitume Congress, Barcelone, II, 409 (2000).

20. O. Ruau, P. Landais, and J. L. Gardette, Fuel 76, 645 (1997).

21. P. Doumenq, M. Guiliano, G. Mille, and J. Kister, Anal. Chim. Acta 242, 137 (1991).

22. D. Faure, J. C. Hipeaux, Y. Guevellou, and A. Legros, Tribo. J. 5, 337 (1999).

23. J. Obiols, SAE 2003-01-1996 (2003)

24. P. Duchesne, F. Stunnenberg, P. Tequi, and S. Lecroq, SAE 2000-01-1814 (2000).

25. C. D. Gamlin, N. K. Dutta, N. Roy Choudhury, D. Kehoe, and J. Matisons, Thermochim. Acta 392-393, 357 (2002).

26. C. Qiu, S. Han, X. Cheng, and T. Ren, Thermochim. Acta 447, 36 (2006).

27. P. Bäckström, J. Am. Chem. Soc. 49, 1460 (1927).

28. H. S. Blanchard, J. Am. Chem. Soc. 81, 4548 (1959). 